\title{
Representation of Illustrations in Primary School Textbooks
}

\author{
Sanja Živanović ${ }^{1}$ \\ Department of General Education Subjects, Faculty of Medicine Foča, \\ University of East Sarajevo, East Sarajevo, Bosnia and Herzegovina \\ Ranka Perućica \\ Department of General Education Subjects, Faculty of Medicine Foča, \\ University of East Sarajevo, East Sarajevo, Bosnia and Herzegovina \\ Olivera Kalajdžić \\ Department of General Education Subjects, Faculty of Medicine Foča, \\ University of East Sarajevo, East Sarajevo, Bosnia and Herzegovina
}

\begin{abstract}
A textbook is a basic and compulsory teaching aid, written on the basis of a prescribed curriculum. The accompanying materials in the textbook are certainly illustrations that, in addition to serving the basic text, can also have a significant effect on the student. The aim of this research was to examine the representation of illustrations in textbooks used from the first to the sixth grade of primary school. An analysis was performed of forty elementary school textbooks approved for use by the Ministry of Education of the Republic of Srpska, with the basic unit of analysis being the illustration in the textbook. The obtained research findings show that in both the first and the second triad, illustrations without humorous elements are more represented, although the number of humorous illustrations is at an enviable level, illustrations directly related to the content of the text predominate, drawings in both triads are most represented, and the largest number of illustrations have an intellectual value. A comparative analysis of the illustrations in the first and second triads shows that the differences can be read in terms of the categories of representation of illustrations on the pages and the functions of facilitating the memory or comprehension of the text. The obtained results are encouraging because they confirm the success of the
\end{abstract}

1 sanja.zivanovic@ues.rs.ba 
assumptions for effective learning in accordance with age characteristics certain illustration requirements have been met, and the study can provide useful information to textbook developers, teachers, parents, and illustrators, given that illustrations are a structural element of a textbook to which students should be referred. The results can also be useful for the shaping and deeper operationalization of art and graphic requirements in the textbook and can influence the improvement of textbook quality standards.

Key words illustration, elementaryschool, textbook, representation, structural elements of the textbook.

\section{Introduction}

In the long history of education, man begins to use the book as the basic source of knowledge about natural and social reality very early. Starting from an early age, a small child is attracted to books, i.e. children's picture books, and later they become a basic means of education. In this paper, we distinguish between the term textbook and book, thinking primarily of the textbook as a school book, as a teaching tool that differs from a book for general use and sets out the basics of scientific knowledge. In the literature, a textbook is defined as a school book in a more or less similar way, using basic determinants such as basic teaching aids, basic, compulsory, main school book, arranged didactic tools, primary source of knowledge, scientific content and content of the curriculum (Avramović \& Vujačić, 2010; Ivić, Pešikan, \& Antić, 2008; Kocić \& Trebješanin, 2001; Maloku, 1987; Milinković, Đokić, \& Dejić, 2008; Potkonjak \& Šimleša, 1989).

Looking at illustrations as a mediator of the obvious, we will mention the ideologue of the primary school, the creator of the textbook theory, the Czech pedagogue John Amos Comenius (Jan Amos Komensky). He was the initiator of many changes in the school, who lived and created in the period of the modern age. The first real textbooks were related to his character and work, and all the principles and pedagogical rules that he introduced are still valid in teaching today, but they are also applicable to the quality of textbooks. He dealt with the problems of organizing schools, especially the issue of teaching, didactic principles and rules. In those areas he put forward a series of ideas that have not lost their significance even today (Krneta, Potkonjak, \& Potkonjak, 1965; Matijević, Bilić, \& Opić, 2016).Comenius considered the textbook as a source of material and also a means of learning, where the first function did not separate it from other printed materials, while the second function had an instructive character (Mitrović, 1994, as cited in Kovačević, 2011). Although it does not lose its basic role, the systematization of basic knowledge and concepts from a particular field of science, the textbook is still suppressed by extracurricular sources of information and media, so it is necessary to supplement it with tools to ensure that students explore, solve, find and are interested (Radomirović, 2004). We can achieve this with a rich modern textbook which, in addition to the basic text from a certain field of science, also contains instructions for the student, tasks, questions, exercises, explanations of unknown words, illustrations and other accompanying elements. All these individual elements, together with the content of the text of a particular field of science, make up the structural elements of a modern textbook. Although all the structural elements of the textbook are equally important, in this paper the emphasis is on the illustrative material, which even in the history of the textbook, together with the basic 
text, formed the structure of the textbook design. The topic of this paper led us to mention the Czech pedagogue, but not by chance. He is also the author of the first illustrated textbook. The structure of that textbook consisted of a basic shorter text and artistic contributions. Over time the design of textbooks has changed significantly, so modern textbooks are full of pictures, maps, charts, photographs, tables, summaries, explanations of unknown words, questions and exercises that help create images in students' minds that last longer than written text. Their function is multiple, cognitive, motivational, affective and aesthetic (Petrović \& Ilić Rajković, 2019). Kovačević points out that it is very difficult to precisely define and group the structural elements of textbooks, and to delimit their function (Kovačević, 2011). For example, the illustrations in the school textbook sometimes carry new information but often also have the function of facilitating the adoption of the material. For this reason, he raises the question of whether illustrations are an element that presents content, presents something new, or facilitates the acquisition of content and knowledge. We would say all of it, for the simple reason that the illustration presents the content in a different way (very suitable for the visual type of student) but also makes the acquisition of knowledge easier and more understandable.

\section{Theoretical framework of illustration analysis and its significance}

Although Comenius theoretically established and explained the principle of obviousness (and compiled the first textbook on the same principle, Orbispictus), he based it on the sensualist theory of cognition according to which sensory experiences played a crucial role in the process of acquiring knowledge. Aristotle also demanded that students should be shown or drawn objects and phenomena in order to better emphasize their properties, so sensory knowledge is the starting point that should continue to serve the aim of thought processing (Vilotijević, 1999), and man himself began to create illustrations very early (for example in caves) as an early aid in the achievements of mankind (Carney \& Levin, 2002).

A significant part of objective reality cannot be observed, because it is beyond the reach of the senses, but that does not mean that it cannot be known in some other way (Laketa \& Vasilijević, 2006, p. 224). The question arises, in what other way, and in the context of this, if experience is taken as a criterion, illustrations would play the role of mediators of obviousness, and the roots are in the cognitive settings of the sensualist theory of cognition.

Mayer's cognitive model of multimedia learning can be closely related to the illustrations in the textbook. The model is based on the assumption that information processing includes two channels: auditory/verbal and visual/image. All channels actively participate in the processing of content, and the student will successfully adopt the material if it is presented through text and illustrations (Mayer, 2011, as cited in Ševa \& Lalić-Vučetić, 2019). The authors also rely on the cognitive theory of double coding according to which verbal and nonverbal information together represent to the cognitive system some stimulus from the environment, so the existence of several modalities speeds up the time of 
information processing, as well as the socio-constructivist approach to learning, according to which the textbook is a book for learning, a means of conveying cultural and intellectual patterns, and illustrations in the service of the basic text and dialogue with the student (Ševa \& Lalić-Vučetić, 2019).

There are various opinions about the need for illustration, ranging from the view that the content should not be illustrated in order for the reader to become his/her own creator of imaginative images, to those who believe that illustration has the function of supplementing the text (Balić-Šimrak \& Narančić-Kovač, 2011). Both are true, but we are committed to the pluralistic functions of illustrative material, because although in addition to the basic text, each individual has his/her own way of imagination. The fact is that younger school age students are just becoming literate, so the illustrative material is much clearer than the text, and at older school ages, the fact is that in addition to the content with illustrations, students better understand the material they learn because information and meaning are visually supplemented. Čalović (2014) points out that the first impression of the textbook is created on the basis of its graphic design, and that the illustrations in the textbook must be related to the content. He also points out that they represent a kind of source of information either as a supplement to the basic text or as an independent source of information, mentally activate students, make the text more interesting and have a motivational and affective function, and emphasizes their special importance at a younger school age. Illustrations in teaching materials have significant benefits for students because they add information and act as a bridge to connect with theory, and also serve as examples of what is given in the text (Fakher, 2011, Omaggio, 1979, Read, 2000, as cited in Elmiana, 2019). As illustrations support the principle of obviousness in the teaching of any subject, and this principle greatly affects the activity and motivation of students, visualization is sometimes crucial for many tasks. The same textual content with and without illustration will not convey the same message, so for example if we deprive students of illustrative material when processing the teaching unit of water circulation, it is quite logical that this phenomenon will not be completely clear. It is an indisputable fact that the visual representation of an object, phenomenon or event is of great importance for experiencing it, because the illustration allows phenomena or events from the near and distant environment, present or past, world of reality or imagination to be understood, actively experienced and helps the child to develop creative forces (Pregrad, 1980). About $90 \%$ of illustrative material is adopted visually, which clearly indicates the importance of illustrative material in textbooks, but in addition the illustration combines psychological, pedagogical-didactic, emotional, artistic-aesthetic, semiotic, social and usable components (Marković, 2015). As part of the analysis of the motivational characteristics of the textbook, Trebješanin et al. (Trebješanin et al. 1990, as cited in Kovačević, 2011) group illustrations into perceptual and intellectual motivational means, while Kovačević points out that if the textbook is valid, it should contain illustrative material explaining why they should be looked at. From the point of view of the didactic-methodical functionality of the textbook, the illustrations belong to significant motivational means, which, in addition to the text, represent another important structural element of the textbook with the function of information carrier (Kovačević, 2011). 
In the process of learning, visual images, i.e. illustrations, play a key role in supporting the effectiveness of teaching materials. They are powerful elements in building students' knowledge, act as a communication tool, and are crucial because they carry some information about the text (Elmiana, 2019). The role of illustrations in the textbook is multiple, and this pluralism is also expressed by Vučković (2014): it develops visual perception and influences various forms of speech expression, has the function of systematization (first textual content and then illustration), is an indispensable tool in interpreting unknown words, affects the affective experience of the characters and thus the activity of students, a connection is established between the part and the whole (Vučković, 2014). The illustration is in the service of independent and creative work by students. If the ways of learning are different, it means including as much diversity as possible in the teaching process, but also independent work in order to make learning as productive as possible. The integration of text and illustration implies the integration of the sensory and the rational, that is, the conceptual and the pictorial. Other authors also support our opinion, stating that illustrations with explanations of the text can help achieve greater cognitive processing of information (Mayer, 1989, as cited in Elmiana, 2019).

Research dealing with the issue of illustrations is still very limited, and some of it is mainly focused on the relationship between text and illustrations (Ševa \& Lalić-Vučetić, 2019), the impact of illustrations on effective learning (Carney \& Levin, 2002), the relationship of text and illustrations or what are the functions of illustration (Marsh \& White, 2003), what are the types of visual representation in textbooks (Petrović \& Ilić Rajković, 2019) or are focused on instructions that refer to independent learning (Kovačević, 2011). The authors of such research rely heavily on a coding system or criteria that are specific to that particular research, depending on what the research goal is and what research tasks are set. Our, although quantitative, indicators cover a wide range of analysis criteria, which is evident in the research tasks.

\section{Research methodology}

Aim and Tasks of the Research. The aim of the research is to examine the prevalence of illustrations in textbooks used in the first two triads (grades 1-6) of primary school in the Republic of Srpska. Based on the set aim, several tasks arise:

T1. Examine the representation of illustrations in relation to the content of the text;

T2. Examine the representation of illustrations on textbook pages;

T3. Examine the representation of illustrations according to the content of humorous elements

T4. Examine the representation of the type of illustration

T5. Examine the spatial representation of page coverage

T6. Examine the representation of illustrations by function

T7. Examine the representation of illustrations by the component they represent

T8. Perform a comparative analysis of the illustrations of the first and second triads

Method. The paper uses the method of theoretical analysis and the descriptive method. Regarding techniques, content analysis has been used, with the illustration being the 
unit of analysis, i.e. an artistic element in the textbook. Criteria for the categorization of units of analysis have also been set out in a tabular overview serving to establish quantitative facts of units of analysis. A quantitative value has been entered into the instrument, and then the number of repetitions has been added up and the percentage calculated for each category separately. The coding system and criteria are inherent in this analysis in accordance with the research tasks. The instrument has been constructed for the purposes of this research. It should be noted that the difference test has not been done, for the simple reason that the difference test only makes sense when measurements are made on samples. A statistically significant difference means that the difference probably also exists in the populations from which the samples have been taken, and our analysis primarily covers the population rather than the sample.

Analyzed Textbooks. The sample consists of forty textbooks used in the first, second, third, fourth, fifth and sixth grade of primary school in the Republic of Srpska, approved for use by the Ministry of Education and Culture. Since all basic textbooks, all courses from the first to the sixth grades, have been analyzed, we can say that the population of basic textbooks used in the first and second triads in primary school have been analyzed. The publisher of all textbooks for all subjects is the Institute for Textbooks and Teaching Aids, except for Orthodox religious studies textbook, whose publisher is the Catechetic Board. The Law on Primary Education of the Republika Srpska states that the curriculum on the basis of which the educational process is realized is adopted by the Ministry in cooperation with the Republic Pedagogical Institute, except for the curriculum of Orthodox religious education adopted by the Ministry at the proposal of the competent church or religious body communities (Article 38, paragraph 1,2). Based on the curriculum, the Institute for Textbooks announces a competition for textbook authors, and then the textbooks are evaluated with three positive reviews, the opinion of the Republic Pedagogical Institute is sought and sent to the Ministry for approval. In the Republika Srpska, textbooks are published by the Institute for Education, while this is not the case in the Federation of Bosnia-Herzegovina where there are as many as thirteen publishing houses. The difference in the entity competencies of the Federation and the Republika Srpska is reflected in the fact that in the Republika Srpska the Ministry is competent, while in the Federation each canton (cantonal pedagogical institutes) is competent separately, so it also applies to textbooks. Practitioners believe that this is a bad textbook policy because the law has left the possibility for each school to choose the textbooks, the authors and the publishing house with which it will work.

\section{Results and Discussion}

After analyzing the illustrations of the first and second triads, numerous facts can be established about the type, presentation and the way in which the illustrations are presented in the textbooks. Based on the set aim, we have been interested in the relationship between illustrations and text, their representation on the page, whether humorous or serious illustrations prevail, the size of illustrations, their function and a set of criteria that are clearly read in research tasks. The analysis of the illustrations is shown in Table 1. 
Table 1

View analysis of illustrations by categories

\begin{tabular}{|c|c|c|c|c|}
\hline Categories of analyis & First triad & Second triad & First triad (\%) & Second triad (\%) \\
\hline \multicolumn{5}{|l|}{ According to the content of the text } \\
\hline $\begin{array}{l}\text { Illustrations that are not directly related to the } \\
\text { content of the text }\end{array}$ & 43 & 111 & 4.5 & 5.3 \\
\hline $\begin{array}{l}\text { Illustrations that are directly related to the } \\
\text { content of the text }\end{array}$ & 887 & 1967 & 93.7 & 94.2 \\
\hline Illustrations not accompanied by text & 17 & 9 & 1.8 & 0.5 \\
\hline \multicolumn{5}{|l|}{ Representation of illustrations on the pages } \\
\hline Pages without illustrations & 128 & 562 & 12 & 21.3 \\
\hline Pages with one illustration & 340 & 1090 & 31.9 & 41.4 \\
\hline Pages with more illustrations & 597 & 978 & 56.1 & 37.3 \\
\hline \multicolumn{5}{|l|}{ Containing elements of humor } \\
\hline Completely serious & 530 & 1513 & 56 & 72.5 \\
\hline Illustrations that contain elements of humor & 417 & 574 & 44 & 27.5 \\
\hline \multicolumn{5}{|l|}{ Illustration type } \\
\hline Drawings & 714 & 1361 & 75.3 & 65.2 \\
\hline Photos & 135 & 584 & 14.2 & 27.9 \\
\hline Graph/Table & 100 & 142 & 10.5 & 6.8 \\
\hline \multicolumn{5}{|l|}{ According to page coverage } \\
\hline Whole page & 220 & 205 & 23.3 & 9.8 \\
\hline $1 / 2$ & 451 & 947 & 47.6 & 45.4 \\
\hline $1 / 4$ & 218 & 801 & 23 & 38.4 \\
\hline Less than $1 / 4$ & 58 & 134 & 6.1 & 6.4 \\
\hline \multicolumn{5}{|l|}{ According to function } \\
\hline $\begin{array}{l}\text { Primarily facilitate the memorization of } \\
\text { materials }\end{array}$ & 409 & 1157 & 43.2 & 55.4 \\
\hline $\begin{array}{l}\text { Primarily facilitate the understanding of the } \\
\text { material }\end{array}$ & 538 & 930 & 56.8 & 44.6 \\
\hline \multicolumn{5}{|l|}{ Presentation of the content component } \\
\hline Intellectual & 763 & 1858 & 80.7 & 89.2 \\
\hline Moral & 26 & 14 & 2.7 & 0.6 \\
\hline Aesthetic & 106 & 197 & 11.2 & 9.4 \\
\hline Work on & 13 & 2 & 1.3 & 0.09 \\
\hline Emotional & 39 & 16 & 4.1 & 0.7 \\
\hline
\end{tabular}

Based on the research on illustrations, Bogomil Karlavaris points out that iconic illustrations are more suitable for children of younger school age, and that at the age of the first triad the illustrations should be cheerful and witty (Karlavaris, 1979, as cited in Kovačević, 2011). In the initial grades, illustrations are the main carrier of content due to undeveloped reading skills, and by mastering reading independence in learning becomes increasingly important (Kovačević, 2011), which can be related to our research and the category of representation of illustrations on textbook pages. Vučković (2014) points out 
that pictures have a dominant place in younger grades and the reason is precisely literacy, so the amount of textual and pictorial material is almost equal. In our study, the percentage of pages without illustrations is lowest (12\%), which coincides with the fact that reading skills in children of younger school age are less developed, so they need more visual content.

Illustrations are meaningless if they do not follow the idea of the text (Kovačević, 2011). Petrović \& Ilić Rajković (2019) indicate that numerous pages from the first to the third grade abound in content that is visually presented. Data from our survey in the first triad also show that the largest number of pages have more than one illustration (56.1\%). The same authors also state that in $82 \%$ of cases drawings dominate as a type of illustration, $12 \%$ of cases are photographs, $5 \%$ maps, and $1 \%$ diagrams, while in the fourth grade photographs dominate. The authors explain the results by the fact that photographs are more realistic while drawings highlight important details and exclude irrelevant ones, which means adapting a certain type of visual representation to the age of the students. Children up to 10 years of age have difficulty using tables, graphs and diagrams (GašićPavišić, 2001, as cited in Petrović \& llić Rajković, 2019). For this reason, differences in the dominant type of illustrations in individual triads are justified. Our study shows that in the younger grades, drawings are the most common type of illustration (75.3\%), followed by photographs (14.2\%) and graphs, tables and diagrams (10.5\%). It is interesting that drawings are most dominant in older classes as well, the number of photos increases, and the number of tables and graphs decreases. Although our study shows agreement in the dominant type of illustrations with the presentation of illustrations in the period far behind us, we must take the data with reservations, but also justify the fact that they are illustrations in geography and nature textbooks, and agree with the research in which it is pointed out that the illustration is determined by the type of book (Lalić Vučetić \& Ševa, 2021). Vučković (2014) in his research noticed a parallel from the concrete and the obvious to the abstract, that is, in older classes the images were more abstract, which agrees with our research findings on the percentage of photographs. According to the results of one study, the largest percentage of illustrations in textbooks for the first grade are those of the iconic type, i.e. imitations of children's drawings or naive painting (Mitrović, 1994, as cited in Kovačević, 2011).

In the younger grades, the characters in the textbook are anthropomorphized, especially in fables and fairy tales (Vučković, 2014), which can be related to our criterion of humorous illustrations. Namely, in the younger grades the percentage of illustrations that contain elements of humor is $44 \%$, while in the second triad it is $27.5 \%$. So, the younger the students, the more illustrations with elements of humor there are. Inevitably, emotions are a powerful companion to teaching. If the textbook and the illustration in it can influence the positive emotional mood of the students, then its function is even greater. The authors Laketa \& Vasilijević (2012) state the principles of emotional control, among which is the activation of humor in teaching. If the illustration in the textbook has elements of humor, then every teacher can point this out when processing that teaching unit, and at least put a smile on the student's face (Laketa \& Vasiljević, 2012). 
When it comes to the size of illustrations or space occupied on a page, one study (Ševa \& Lalić-Vučetić, 2019) noticed a difference in the size of the space occupied by illustrations, but it was influenced by the physical size of the text and font size. Primary school textbooks, by various publishers, were dominated by half-page illustrations, while others were dominated by full-page illustrations, which was directly related to text size and font size. Less space on the page meant less detailed illustration. Also, in the same study, a smaller illustration did not show the dynamics of the relationship described in the text. In our analysis, we have obtained indicators that in the first triad the largest number of illustrations occupies the entire page $(23.3 \%)$ or half of the page $(47.6 \%)$, while in the second triad this number decreases (full page $-9.8 \%$, half of the page $45.4 \%$ ). We could also relate these facts to the function of memory and comprehension from our category. If the illustrations do not show the dynamics of the relationship and if they are smaller, they will have less effect on understanding and more on the memory of the material. Namely, the results of our research coincide in this context. In the first triad, the largest percentage of illustrations occupy the entire or half of the page, and accordingly there is a higher percentage of illustrations that primarily facilitate the understanding of the material $(56.8 \%)$. In the second triad this is not the case. The number of illustrations occupying more space decreases, and the memory function increases (55.4\%).

There is no difference when it comes to linking illustrations to textual content. In both the first and second triads, most illustrations (over 90\%) are directly related to the content of the text. Those illustrations that are not related to the content of the lesson at all make up $1.8 \%$ in the first triad, and $0.5 \%$ in the second triad. The results of one study coincide with ours, indicating that the largest number of illustrations highlight claims in the linguistic part of the text, but that there are also those that do not deal with the text or provide any information about it, called decorative illustrations (Kress \& Van Leeuwen, 2006, as cited in Elmiana, 2019). Also, we were interested in which component, or side of personality development the illustrations in the basic textbooks represent. Most illustrations represent the intellectual component in both the first $(80.7 \%)$ and the second triads (89. 2\%), but when we compare the first and second triads we can notice that the representation of other components is higher in the first than in the second triad. The explanation for this can be found in the fact that the basics of all components are adopted at a younger age, and later only upgraded, so in the first grades the illustrations are much more oriented towards the other components than in the older grades.

The results of a qualitative research in which the goal was to determine how teachers and illustrators perceive illustrations in a textbook, can be related to the data of our research. In one study (Peterson, 2016, as cited in Lalić Vučetić \& Ševa, 2021), illustrations were classified according to the following system: examples of pages where the text is superior to the illustration, i.e. the text is in the foreground and the illustration is somewhere in the corner of the page; the text is subordinate to the illustration; the text and the illustration are integrated. According to the above, we could say that the analysis of our obtained data, the representation of illustrations that occupy $1 / 4$ pages or less have a percentage of $29.1 \%$ in the first triad, while in the second they amount to $44.4 \%$. We 
could say that the text here is superior to the illustration. The percentage of pages with an illustration that occupies the entire page is $23.3 \%$ in the first triad and $9.8 \%$ in the second triad. The text in relation to the illustrations that occupy an entire page in the textbook is logically subordinated. Through the interview, the illustrator stated that more illustrations are needed for children of a younger age because in that development period, students rely more on the picture, and that the two basic dimensions that determine illustration are the type of book and the requirements of the publishing house. Teachers also point out that the dominance of the text at a younger age can be a trigger for demotivation (Lalic Vučetić \& Ševa, 2021). In the presented tabular overview, we can notice that there are more pages with more illustrations, as well as illustrations that occupy the entire space of the page in textbooks for younger school ages. The illustrator's statement that they very often adapt to the requirements of the publishing house, and that they often have the task of filling the physical space on the page, speaks in favor of a more detailed operationalization of art and graphic requirements which will be discussed in the conclusion.

\section{Pedagogical implications and conclusion}

This study can provide useful information to textbook developers, teachers, parents, and illustrators, given that illustrations are a structural element of a textbook to which students should be referred. Given the role that illustrative representations play in the cognitive process, any research on this topic is significant, useful, and necessary. The student, the teacher, the teaching content and the material and technical basis of teaching are not without reason a didactically inseparable quadrangle. They are interconnected, influencing each other. Therefore, the observation and use of illustrations depends not only on the textbook, but also on the teacher and his/her use of illustrations. In order to achieve learning goals and objectives, general and individual, the structural elements of textbooks must be interconnected. The textbook has progressed from a source of information to a means for interactive learning, so it is not only a concretization of the curriculum, but also a means of shaping the culture and technique of intellectual work, fulfilling a dialogic role with the student, becoming a mediator of the obvious, a mediator between knowledge and students' age. The illustrations in the textbook are not read on their own, so it is necessary to refer students to the structural elements of the textbook and participate with them in the interpretation of the illustrations.

Quality textbooks are part of the quality palette of the educational process, and for that reason the authors popularize research of this kind, which opens space for further research. The document Strategy for the Development of Education in the Republic of Srpska states that the textbook serves both students and teachers. The former for understanding and adopting the teaching content, and the latter as a guide based on which they interpret the teaching content. According to this view, the authors of this paper turn the guidelines towards observing the illustrative material in the textbook that accompanies the text. By looking at illustrations as mediators of obviousness, they can represent the basis of knowledge and start the thought process, collecting material, connecting with the text and research curiosity of students to learn. Illustrations can mediate between a 
natural phenomenon (water circulation in nature, for example) and students' awareness of a particular material. Judging by the obtained data, it can be concluded that the illustrations follow the text they are with, contribute to understanding, develop educational values with special emphasis on the intellectual component, although the Textbook Quality Standards (2020) emphasize aesthetic values in aesthetic and technical characteristics of textbooks. According to the analysis of illustrations, we notice that the smallest number of illustrations takes up less than a quarter of a page, which is also in line with the requirement for the font of visual representations (not less than $8 \mathrm{pt}$ ). If we were to examine language standards, the requirements of script, ijekavian pronunciation, grammar, foreign expressions, and sentence construction are clearly operationalized. This is not the case with the illustrative requirements, and it is also a shortcoming of this research. Dosing would complete and enrich the discussion, but that certainly does not mean that the authors should not deal with them, because any previous research can be a guiding idea for the next one or encourage the creation of operationalized indicators. For that reason, the paper can also represent the initial steps that outline the problems of the graphic and graphic requirements of the textbook. It can be concluded that it is necessary to make certain changes in textbook quality standards and even more extensive and deeper operationalization for illustrative requirements, which would facilitate the work of textbook authors and illustrators, and on the other hand, improve the teaching process by observing and interpreting them. In addition, one of the tasks of teachers should be to put more emphasis on illustrations, observing illustrative material and interpretation, and for students it would help to adopt, understand, remember the material that is directly related to a particular illustration. Finally, we give one example from practice which we came across quite by accident, and thinking about everyday events can arouse research curiosity:

During the study of the poem by the Serbian poet and writer Dušan Radović, the students looked at a humorous illustration of a blue rabbit. After observing the illustration, analyzing all the details, reading the poem and discussing it, the students arrived at the question on their own: does such a rabbit exist? Did the hunter fantasize? Why does the writer describe the rabbit as a fearless hero who has numerous qualities, coming to the conclusion that the poem actually disarms the myths of hunting stories. At that moment, the teacher realized that dwelling on the humorous illustration actually made the students think.

\section{References:}

Avramović, Z., \& Vujačić, M. (2010). Odnos kvalitativne i kvantitativne metode istraživanja školskih udžbenika. Teme, 34(2), 447-461.

Balić-Šimrak, A., \& Narančić Kovač, S. (2011). Likovni aspekti ilustracije u dječjim knjigama i slikovnicama. Dijete, vrtić, obitelj: Časopis za odgoj i naobrazbu predškolske djece namijenjen stručnjacima i roditeljima, 17(66), 10-12.

Carney, R. N., \& Levin, J. R. (2002). Pictorial illustrations still improve students's learning from text. Educational psychology review, 14(1), 5-26. https://doi.org/1023/a:1013176309260 
Čalović, S. (2014). O nekim smjernicama za oblikovanje savremenih udžbenika. In V. Milisavljević (Ed.), Nauka i globalizacija (pp.875-888). Pale: Filozofski fakultet.

Elmiana, D. S. (2019). Pedagogical representation of visual images in EFL textbooks: a multimodal perspective. Pedagogy, Culture \& Society, 27(4), 613-628. https://doi.org/10.1080/14681366.201 9.1569550

Ivić, l., Antić, S., \& Pešikan, A. (2008). Vodič za dobar udžbenik: opšti standardi kvaliteta udžbenika. Novi Sad: Platoneum.

Kocić, Lj., \&Trebješanin, B. (2001). Osnovnoškolski udžbenik kao predmet razmatranja. In B. Trebješanin i D. Lazarević (Eds.), Savremeni osnovnoškolski udžbenik, teorijsko-metodološke osnove (pp.15-18). Beograd: Zavod za udžbenike i nastavna sredstva.

Kovačević, Z. (2011). Instrukcije za samostalno učenje u udžbenicima za mlađe razrede. Beograd: Univerzitet u Beogradu, Učiteljski fakultet.

Krneta, Lj., Potkonjak, M., \& Potkonjak, N. (1965). Pedagogija. Beograd: Zavod za izdavanje udžbenika.

Laketa, N., \& Vasilijević, D. (2006). Osnovi didaktike. Užice: Učiteljski fakultet.

Laketa, N., \& Vasilijević, D. (2012). Obrazovanje i usavršavanje nastavnika. Užice: Učiteljski fakultet.

Lalić Vučetić, N., \& Ševa, N. (2021). Odnos teksta i ilustracije:perspektiva ilustratora i učitelja. Inovacije u nastavi, 34(1), 44-62. https://doi.org/10.5937/inovacije2101044L

Maloku, S. (1987). Oblikovanje udžbenika geografije na Kosovu. Hrvatski geografski glasnik, 49(1), 163-167.

Marković, S. Ž. (2015). Cultural and lingual-cultural aspect of illustrated materials in primary school course books and manuals for Russian language. Inovacije u nastavi-časopis za savremenu nastavu, 28(1), 113-129. https://doi.org/10.5937/inovacije1501113M

Marsh, E. E., \& White, M. D. (2003). A taxonomy of relationships between images and text. Journal of Documentation, 59(6), 647-672. https://doi.org/10.1023/a:1013176309260.

Matijević, M., Bilić, V., \& Opić, S. (2016). Pedagogija za učitelje i nastavnike. Zagreb: Školska knjiga.

Milinković, J., Đokić, O., \& Dejić, M. (2008). Model udžbenika kao osnove aktivnog učenja u nastavi matematike. Inovacije u nastavi, 21(1), 70-79.

Petrović, Đ. S., \& Ilić Rajković, A. (2019). Vizuelno predstavljanje u udžbenicima zemljopisa i poznavanja prirode u Srbiji u periodu od 1945. do 1966. godine. In J. Milutinović, (Ed.), Zbornik odseka za pedagogiju (pp. 49-69). Novi Sad: Filozofski fakultet.

Potkonjak, N., \& Šimleša, P. (1989). Pedagoška enciklopedija 1-2. Beograd: Zavod za udžbenike i nastavna sredstva.

Pravilnik o standardima kvaliteta udžbenika (2020). Službeni glasnik Republike Srpske, br. 4/21.

Pregrad, Z. (1980). Porodični odgoj. Sarajevo: IGKRO „Svjetlost“, OOUR Zavod za udžbenike.

Radomirović, V. (2004). Neke psihološke osnove savremenih osnovnoškolskih udžbenika. Godišnjak za psihologiju, 3, 165-181.

Strategija razvoja obrazovanja Republike Srpske 2016-2021 (2016). Banja Luka. Vlada Republike Srpske, Ministarstvo prosvjete i kulture.

Ševa, N., \& Lalić-Vučetić, N. (2019). Odnos teksta i ilustracije: Analiza savremenih bukvara. Zbornik instituta za pedagoška istraživanja, 51(2), 507-572. https://doi.org/10.2298/ZIPI1902507S

Vilotijević, M. (1999). Didaktika 1. Beograd: Naučna knjiga. 
Vučković, D. (2014). O ilustraciji u osnovnoškolskoj nastavi književnosti. In V. Jovanović \& T. Rosić (Eds.), Književnost za decu u nauci i nastavi 18 (pp. 397-411). Jagodina: Fakultet pedagoških nauka Univerziteta u Kragujevcu.

Zakon o osnovnom vaspitanju i obrazovanju (2017). Službeni glasnik Republike Srpske, br. 44/17.

Примљено: 18. 02. 2021.

Коригована верзија примљена: 08. 10. 2021.

Прихваћено за штампу: 02. 11. 2021.

\title{
Заступљеност илустрација у уџбеницима основне школе
}

\author{
Сања Живановић \\ Катедра општеобразовних предмета, Медицински факултет Фоча, \\ Универзитет у Источном Сарајеву, Источно Сарајево, Босна и Херцеговина

\section{Ранка Перућица} \\ Катедра општеобразовних предмета, Медицински факултет Фоча, \\ Универзитет у Источном Сарајеву, Источно Сарајево, Босна и Херцеговина

\section{Оливера Калајџић} \\ Катедра општеобразовних предмета, Медицински факултет Фоча, \\ Универзитет у Источном Сарајеву, Источно Сарајево, Босна и Херцеговина
}

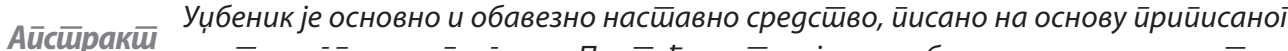

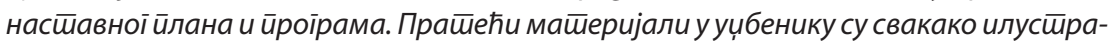

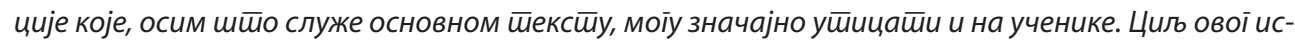

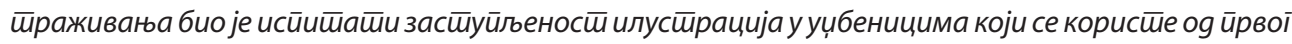
gо шесйої разреgа основне школе. Анализа је извршена на чеширgесей основношколских уибе-

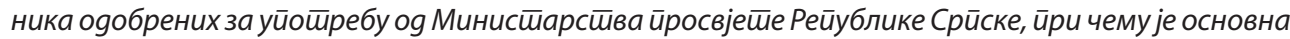
јеgиница анализе илусйрација у учбенику. Добијени налази исйраживањ а ӣоказују gа су и у ӣрвој

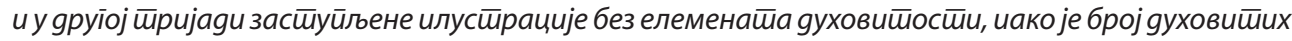
илусирација на завияном нивоу, иреовлађују илусирације које су gирекйно везане за саяржај

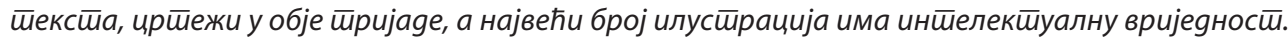

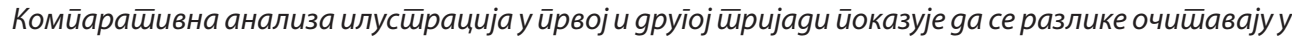
йоїлеgу кайеїорија ӣреgсйављање илусйрација на сиираницама и функција олакшавања йам-

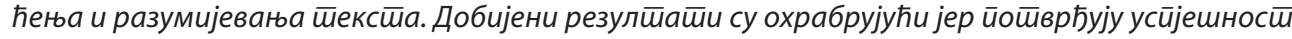

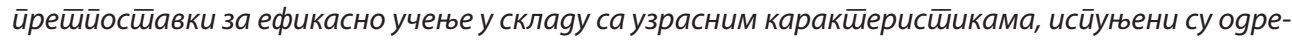

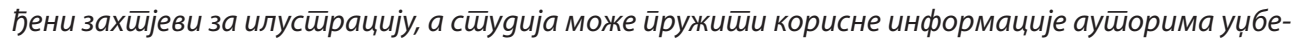

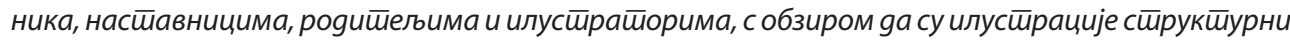

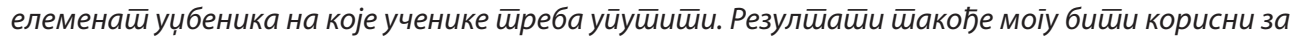

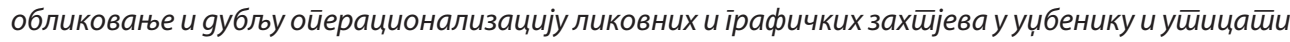

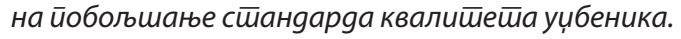

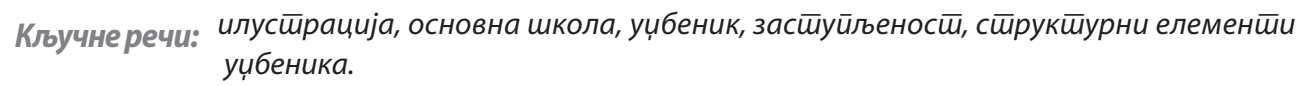




\title{
Наличие иллюстраций в учебниках начальних классов
}

\section{Саня Живанович}

Кафедра общеобразовательных предметов, Медицинский факультет в г. Фоча, Восточносараевский университет, Восточное Сараево, Босния и Герцеговина

\section{Ранка Перучица}

Кафедра общеобразовательных предметов, Медицинский факультет в г. Фоча, Восточносараевский университет, Восточное Сараево, Босния и Герцеговина

\section{Оливера Калайджич}

Кафедра общеобразовательных предметов, Медицинский факультет в г. Фоча, Восточносараевский университет, Восточное Сараево, Босния и Герцеговина

\begin{abstract}
Резюме Учебник являеш̄ся основным и обязайельным учебным ӣособием, найисанным в соо-

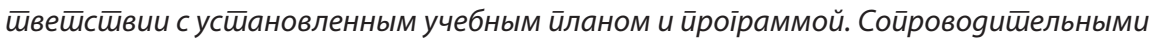

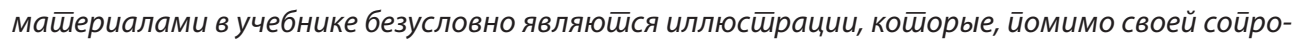

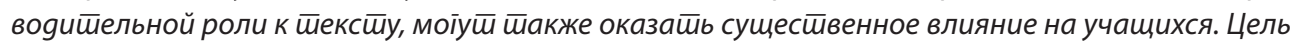
gанно исллеgования - изучиш̄ь наличие иллюсӣраций в учебниках, исйользуемых с йервоїо ӣо шесшиой класс начальной школы. Анализом охвачено сорок учебников gля начальной школы, о ообренных gля исӣользования Минисиеерсиивом образования Ресӣублики Сербской, а основной еgиницей анализа являлась иллюсирачия в учебнике. Полученные резульшиайы исслеgования

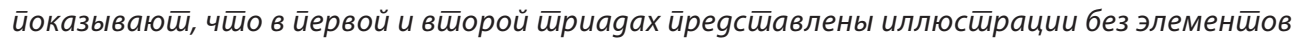

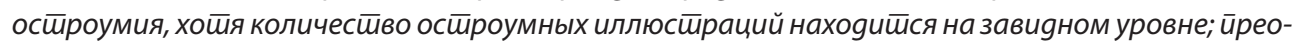

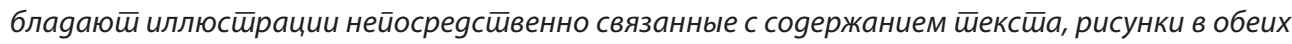

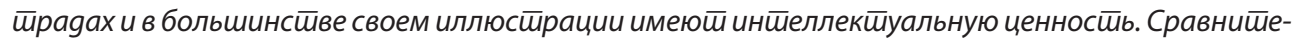

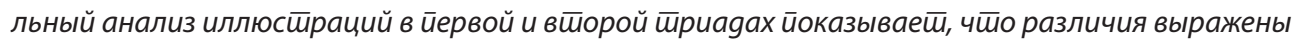

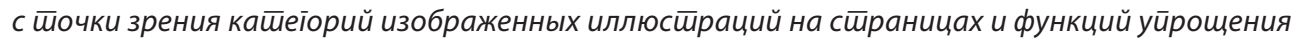

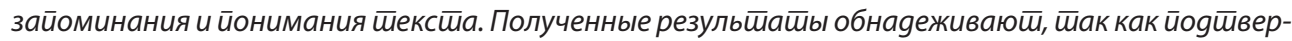

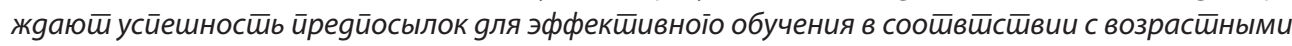

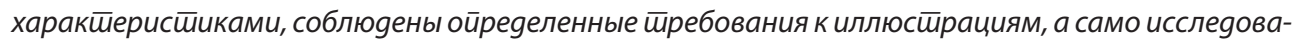

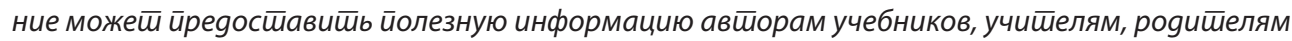

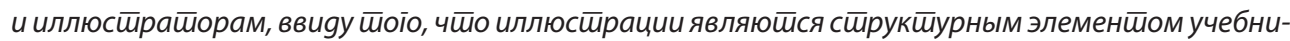

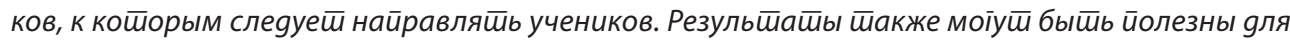
формирования и более іллубокой реализации шрребований к искуссӣву и ірафике в учебниках, а

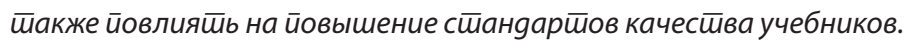

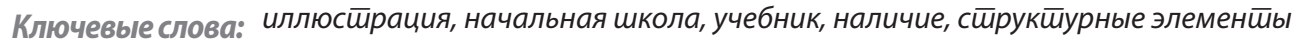
учебника. 